\title{
Highlights in Seagrasses' Phylogeny, Physiology, and Metabolism: What Makes Them Special?
}

\author{
Jutta Papenbrock \\ Institute of Botany, Leibniz University Hannover, Herrenhäuser Straße 2, 30419 Hannover, Germany \\ Correspondence should be addressed to Jutta Papenbrock, jutta.papenbrock@botanik.uni-hannover.de \\ Received 1 October 2012; Accepted 20 November 2012 \\ Academic Editors: M. Kwaaitaal and I. Zarra \\ Copyright () 2012 Jutta Papenbrock. This is an open access article distributed under the Creative Commons Attribution License, \\ which permits unrestricted use, distribution, and reproduction in any medium, provided the original work is properly cited.
}

The marine seagrasses form an ecological and therefore paraphyletic group of marine hydrophilus angiosperms which evolved three to four times from land plants towards an aquatic and marine existence. Their taxonomy is not yet solved on the species level and below due to their reduced morphology. So far also molecular data did not completely solve the phylogenetic relationships. Thus, this group challenges a new definition for what a species is. Also their physiology is not well understood due to difficult experimental in situ and in vitro conditions. There remain several open questions concerning how seagrasses adapted secondarily to the marine environment. Here probably exciting adaptation solutions will be detected. Physiological adaptations seem to be more important than morphological ones. Seagrasses contain several compounds in their secondary metabolism in which they differ from terrestrial plants and also not known from other taxonomic groups. Some of these compounds might be of interest for commercial purposes. Therefore their metabolite contents constitute another treasure of the ocean. This paper gives an introduction into some of the most interesting aspects from phylogenetical, physiological, and metabolic points of view.

\section{Introduction}

Seagrasses are a paraphyletic group of marine hydrophilus angiosperms which evolved three to four times from land plants back to the sea. The following characteristics can be used to define a seagrass species. It lives in an estuarine or in the marine environment, and nowhere else. The pollination takes place underwater with specialized pollen. The seeds which are dispersed by both biotic and abiotic agents are produced underwater. The seagrass species have specialized leaves with a reduced cuticle, an epidermis which lacks stomata and is the main photosynthetic tissue. The rhizome or underground stem is important in anchoring. The roots can live in an anoxic environment and depend on oxygen transport from the leaves and rhizomes but are also important in the nutrient transfer processes [1]. Seagrasses profoundly influence the physical, chemical, and biological environments of coastal waters. Though seagrasses provide invaluable ecosystem services by acting as breeding and nursery ground for a variety of organisms and promote commercial fisheries, many aspects of their physiology are not well investigated. Several studies have indicated that seagrass habitat is declining worldwide [2]. Ten seagrass species are at elevated risk of extinction (14\% of all seagrass species) with three species qualifying as endangered. Seagrass loss and degradation of seagrass biodiversity will have serious repercussions for marine biodiversity and the human population that depends upon the resources and ecosystem services that seagrasses provide [3]. This paper aims to highlight some fascinating and sometimes hidden aspects of seagrass physiology and their metabolites and focuses on the distinctiveness of seagrasses also from an evolutionary point of view. Maybe it encourages protecting the invaluable ecosystem of seagrass meadows.

\section{Origin of Seagrasses}

Seagrasses do not represent the link between marine algae and terrestrial higher plants. This unique ecological group represents the "whales" of the plant kingdom. Similarly to whales seagrasses returned to sea and secondarily colonized marine habitats [4]. The recolonization occurred exclusively from the monocot order Alismatales and appears to be evolutionary unique. The adaption to marine environments 
is regarded as an analogous adaption and took place at least three times independently during the evolution of seagrasses [5]. Only four families of higher plants, Posidoniaceae, Cymodoceaceae, Hydrocharitaceae, and Zosteraceae, contain exclusively marine species [6] (Figure 1; Table 1). The Posidoniaceae, which are monogeneric, and the Zosteraceae, consisting of the four genera, Heterozostera, Phyllospadix, Nanozostera, and Zostera, are exclusively marine organisms. Likewise the Cymodoceaceae represents a solely marine family and encompasses the highest variety of genera (Amphibolis, Cymodocea, Halodule, Syringodium, and Thalassodendron). The Hydrocharitaceae, that mainly comprise genera restricted to freshwater habitats, also include three marine genera (Enhalus, Halophila, and Thalassia) [5]. Seagrasses can therefore be regarded as an ecological group, occurring worldwide in different climatic zones (Table 1) and sharing various metabolic features with their terrestrial counterparts. However, their metabolism must have undergone several adaptations to survive and colonize shores and oceans worldwide (see Section 5).

Molecular approaches shed light on which seagrass genes have diverged from their terrestrial counterparts via an initial aquatic stage characteristic of the order and to the derived fully-marine stage characteristic of seagrasses. Positively selected genes are associated with general biological pathways such as metabolic pathways, translation, and photosynthesis, probably associated with the $\mathrm{Na}^{+}$toxicity of these processes [7].

When did the seagrass genera evolve? There are age estimates for families of monocots published. The Cymodoceaceae have a crown node age of 61 Mya and a stem node age of $67 \mathrm{Mya}$, the Hydrocharitaceae a crown node age of $75 \mathrm{Mya}$ and a stem node age of $88 \mathrm{Mya}$, for the Posidoniaceae only a stem node age of 67 Mya can be estimated, and the Zosteraceae appeared only recently with a crown node age of 17 Mya and a stem node age of 47 Mya [8].

\section{Morphological Traits and Molecular Markers for Seagrass Differentiation}

3.1. Morphological Traits. Although on a global scale seagrasses represent less than $0.1 \%$ of the angiosperm taxa, the taxonomical ambiguity in delineating seagrass species is high. The taxonomy of several genera is unsolved. While seagrasses are capable of performing both, sexual and asexual reproduction, vegetative reproduction is common and sexual progenies are always short lived and epimeral in nature (Figure 1; Table 1). This makes species differentiation often difficult, especially for nontaxonomists since the flower as a distinct morphological trait is missing. Some seagrass genera can hardly be distinguished by their morphology at all, for example, examples from the Halophila complex (Figure 1; [9]). There are no morphological characters that can distinguish the seagrasses from other aquatic plants. The only character in which most of them differ from the other aquatic plants is the filiform pollen or the strings of spherical pollen. However, it is not known what the special advantage of these may be for life in the marine environment [6].
The Halophila section is known as one of the most complex taxonomic challenges $[10,11]$. Phenotypic plasticity is a problem not only between populations, but also between species, at least for complex ones. Especially the Halophila ovalis complex has little genetic variation but wide morphological plasticity [12]. Difficulties on morphological classification occur during species identification due to overlaps of morphological traits among species of Halophila (Figure 1). Current phylogenetic relationships in the order Alismatales based on molecular data compared with morphological were studied by $\mathrm{Li}$ and Zhou [13] or more specifically for the Hydrocharitaceae family by Chen et al. [14]. In general, morphological data sets of seagrasses contain poor phylogenetic signals and an incongruence between DNA and morphological results is observed [13, 14].

3.2. Molecular Marker Including DNA Barcoding. Due to the reduced morphological traits and the high phenotypic plasticity molecular methods might help to clarify the taxonomy and also help the nontaxonomists to differentiate among different seagrass taxa. However, so far there is no data set of molecular markers available which resolves all taxonomically accepted seagrass species, and more work has to be done to close this gap of knowledge. The development of a DNA barcoding system assisting also nontaxonomists to identify regional seagrass species was successful. Based on the recommendations of the Consortium for the Barcoding of Life (CBOL), $r b c \mathrm{~L}$ and $m a t \mathrm{~K}$ were used. Tree- and characterbased approaches demonstrate that the $r b c \mathrm{~L}$ sequence fragment is capable of resolving up to family and genus level. Only matK sequences were reliable in resolving species and partially the ecotype level. Additionally, a plastidic gene spacer was included in the analysis to confirm the identification level. Although the analysis of these three loci solved several nodes, a few complexes remained unsolved, even when constructing a combined tree for all three loci [15]. The addition of a nuclear ITS marker constitutes a good completion of the $r b c \mathrm{~L} /$ mat K marker system (Table 2) ([16]; unpublished own data). However, for population studies AFLP or microsatellite analysis has to be used because the resolution of the other marker systems is not sufficient ([16]; unpublished own data).

\section{Physiology of Seagrasses}

4.1. Conditions for Seagrass Growth. While there are few or no particular structures in seagrass that can be identified as unique in terms of structural adaptation to the marine environment, there is a suite of characters, which together can be taken as representative of seagrasses. These include strap-shaped leaves and anatomical reinforcement to resist wave action, adaptation of leaves to carry out photosynthesis in a seawater environment, osmotic adjustment and other adaptations within the leaf blade and leaf sheath, modifications to rhizomes and roots for different substrates, pollination by hydrophily, reduction in the layers of the pollen wall, and several unique features associated with seed formation and dispersal mechanisms [17]. However, there 


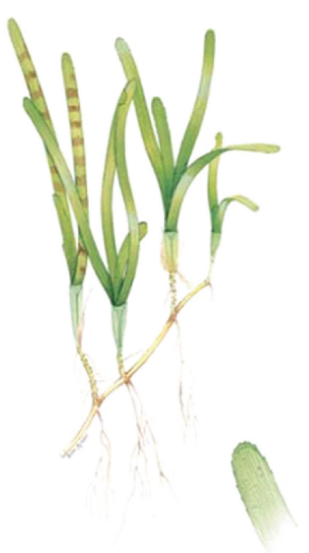

(a)

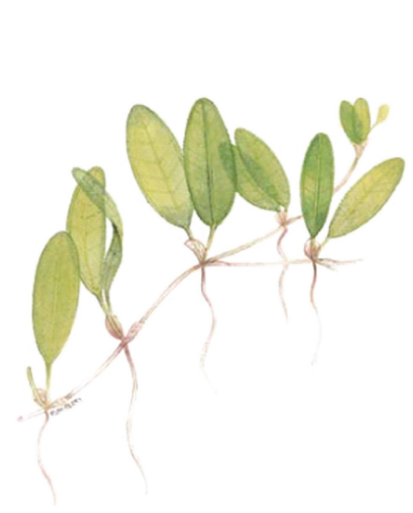

(e)

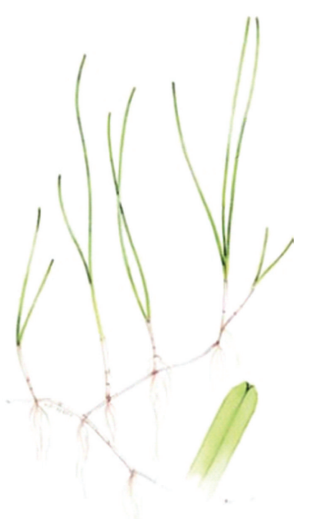

(b)

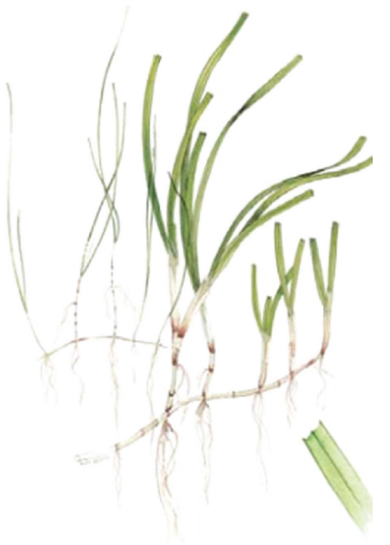

(c)

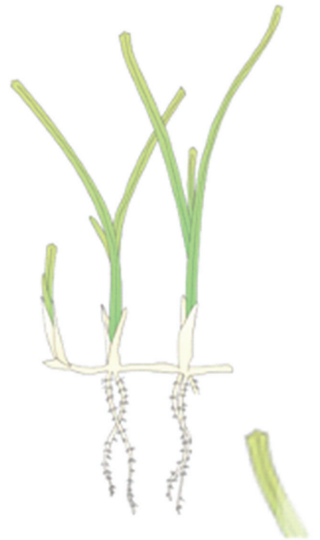

(d)

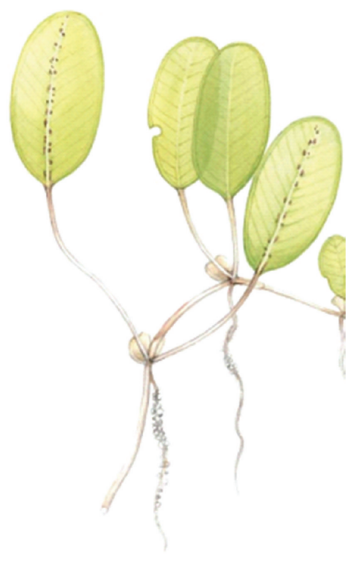

(f)

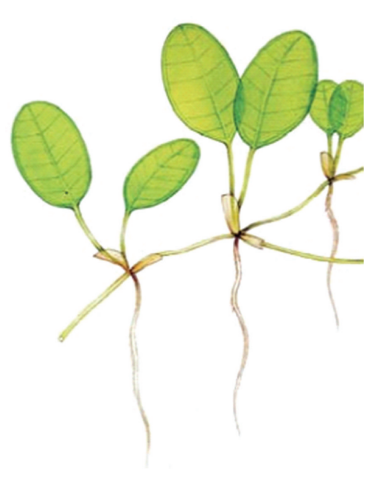

(g)

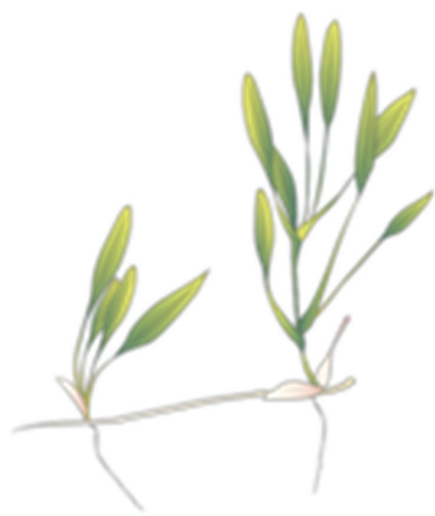

(h)

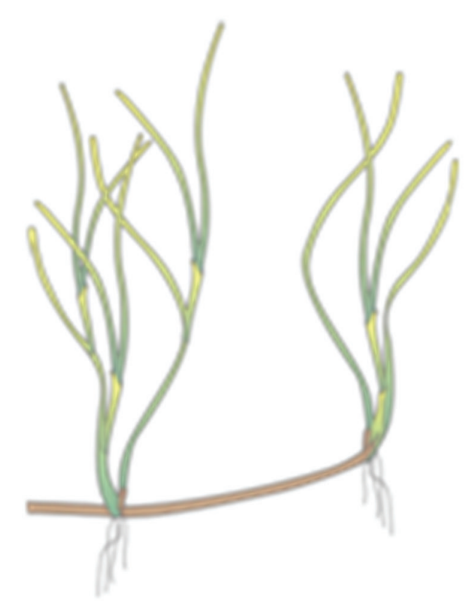

(i)

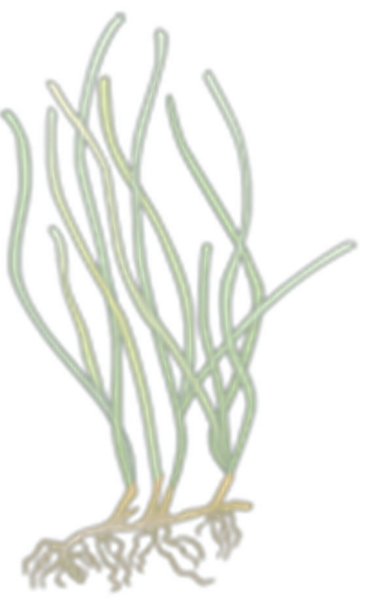

(j)

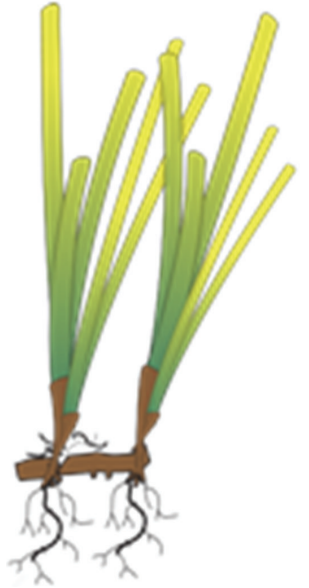

(k)

FIgure 1: Schematic illustrations of seagrass members of the four different families. Cymodoceaceae: (a) Cymodocea serrulata, (b) Halodule pinifolia, (c) Halodule uninervis, (d) Halodule wrightii. Hydrocharitaceae: (e) Halophila decipiens, (f) Halophila ovalis, (g) Halophila ovata, (h) Halophila beccarii. Zosteraceae: (i) Zostera marina, (j) Zostera noltii. Posidoniaceae: (k) Posidonia australis (source of the single schemes: http://ian.umces.edu/symbols/). 
TABle 1: Seagrass species sensu stricto according to the definitions by Larkum et al. [1]. The table shows combined data from Ackerman [101] and Short et al. [18].

\begin{tabular}{|c|c|c|c|c|}
\hline Family & Genus & $\begin{array}{c}\text { Reproductive ecology } \\
\text { Mode }\end{array}$ & $\begin{array}{c}\text { Reproductive ecology } \\
\text { Decliny }\end{array}$ & Distribution \\
\hline \multirow{3}{*}{ Hydrocharitaceae } & Enhalus (1) & Surface & Monoecious & $5^{*}$ \\
\hline & Thalassia (2) & Submarine & Dioecious & 2,5 \\
\hline & Halophila (14) & Submarine & Monoecious and dioecious & $2,3,4,5,6$ \\
\hline \multirow{5}{*}{ Cymodoceaceae } & Amphibolis (2) & Submarine & Dioecious & 6 \\
\hline & Cymodocea (4) & Submarine & Dioecious & $1,3,5$ \\
\hline & Halodule (8) & Submarine & Dioecious & $1,2,5$ \\
\hline & Syringodium (4) & Submarine & Dioecious & 2,5 \\
\hline & Thalassodendron (2) & Submarine & Dioecious & 5,6 \\
\hline Posidoniaceae & Posidonia (1) & Submarine & Bisexual & 3,6 \\
\hline \multirow{4}{*}{ Zosteraceae } & Heterozostera (1) & Submarine & Monoecious & 6 \\
\hline & Phyllospadix (5) & Submarine & Dioecious & 4 \\
\hline & Nanozostera (8) & Submarine and surface & Monoecious & $1,3,4,5,6$ \\
\hline & Zostera (4) & Submarine and surface & Monoecious & $1,3,4,5,6$ \\
\hline
\end{tabular}

*1 Temperate North Atlantic, 2 Tropical Atlantic, 3 Mediterranean, 4 Temperate North Pacific, 5 Tropical Indo-Pacific, 6 Temperate Southern Oceans.

TABLE 2: Overview about molecular studies of seagrasses using different molecular marker systems.

\begin{tabular}{|c|c|c|}
\hline Taxon & Loci used & Source \\
\hline Alismatales & $r b c \mathrm{~L}$ & Les et al. 1997 [5], Li and Zhou 2009 [13] \\
\hline Hydrocharitaceae & $r b c \mathrm{~L}, \operatorname{mat} \mathrm{K}$ & Tanaka et al. 1997 [102] \\
\hline Hydrocharitaceae & $18 \mathrm{~S}, r b c \mathrm{~L}, m a t \mathrm{~K}, \operatorname{trnK} 5^{\prime}$ intron, $r p o \mathrm{~B}, r p o \mathrm{C} 1, c o b, a t p 1$ & Chen et al. 2012 [14] \\
\hline Halophila & ITS1, 5.8S, ITS2 & Uchimura et al. 2008 [11] \\
\hline Halophila & ITS1, 5.8S, ITS2 & Waycott et al. 2002 [103] \\
\hline Halophila & ITS1, 5.8S, ITS2 & Short et al. 2010 [12] \\
\hline Halodule & $r b c \mathrm{~L}, p h y \mathrm{~B}, t r n \mathrm{H}-p s b \mathrm{~A}$ & Ito and Tanaka 2011 [104] \\
\hline Zostera & $r b c \mathrm{~L}, \operatorname{mat} \mathrm{K}$ & Kato et al. 2003 [105] \\
\hline Zostera & $r b c \mathrm{~L}, \operatorname{trn\mathrm {K}}$, ITS & Les et al. 2002 [106] \\
\hline All seagrass genera & $\operatorname{trn} \mathrm{L}$ & Procaccini et al. 1999 [107] \\
\hline Halodule, Posidonia, Ruppia & $\operatorname{trn} \mathrm{L}, \mathrm{ITS}$ & M. Waycott, pers. comm. \\
\hline
\end{tabular}

are no specific morphological (secondary) adaptations to the marine environment.

Obviously, the physiological adaptations are more important than morphological ones and seagrasses must have evolved very special physiological mechanisms to deal with large fluctuations in salinity. Seagrasses generally have high light requirements, with an average of $10 \%$ of surface light. Some species, such as Halophila, often grow in deeper water and have been shown to survive at approximately $5 \%$ of surface light. Often the distribution of seagrasses is primarily limited by the amount of light that reaches the sediment. Therefore increasing turbidity by resuspension of fine sediment or anthropogenic factors leads to a decrease of seagrass growth and abundance. Seagrasses can be categorized on the basis of their growth forms, which range from small plants with thin leaves (e.g., Halophila, Halodule) to large plants with thick leaves (e.g., Thalassia, Enhalus, and Posidonia). This gradient in seagrass morphology and turnover rates is also reflected in aspects of distribution, ecophysiology, and ecological interactions. These large variations in morphology and ecological function of different seagrass species influence, how they interact with higher trophic levels and the type of habitat they provide [18].

Seagrass photosynthesis, particularly in shallow and confined environments, is thus constrained by low $\mathrm{CO}_{2}$ concentration and low molecular diffusion associated with the boundary layer around the leaves. The greatest physiological and biochemical adaptation is probably the conversion of $\mathrm{HCO}_{3}{ }^{-}$in seawater into $\mathrm{CO}_{2}$ presumably by anhydrase enzymes at the outer tangential walls of epidermal cells and also the presence of a proton pump at the plasmalemma of seagrass leaves. However, this applies also to most freshwater plants. The primary form of dissolved inorganic carbon in the marine environment is bicarbonate $(90 \%)$, while $\mathrm{CO}_{2}$ represents a minor fraction $(0.5-1 \%)$ for seawater at $\mathrm{pH}$ 8.1-8.3 (and less than $0.1 \%$ at the higher ranges of $\mathrm{pH}$ ) [19].

The ability to utilize $\mathrm{HCO}_{3}{ }^{-}$could be one of the traits evolved in the last common ancestor branch. In contrast, a set of signals of positive selection specific to the Zostera lineage could relate to the biochemical mechanism used in 
carbon fixation. Seagrasses have long been regarded as $\mathrm{C}_{3}$ plants, but physiological measurements have gathered indications that several seagrass species, including $Z$. marina, are $\mathrm{C}_{3}-\mathrm{C}_{4}$ intermediates or have various carbon-concentrating mechanisms to aid the ribulose-1,5-bisphosphate carboxylase/oxygenase (RuBisCO) enzyme in carbon acquisition [20, 21]. Seagrasses are able to activate different mechanisms to cope with conditions of light-limitation and shifted light spectrum through long-lasting metabolic adjustments including downregulation of RuBisCO, enhanced proteolysis and changes in the antenna complex [2]. Seagrasses do not have any stomata, therefore no crassulacean acid metabolism (CAM) is induced. Analyses have also almost excluded the possibility of $\mathrm{C}_{4}$ metabolism in seagrasses on the evidence from $\delta^{13} \mathrm{C}$ experiments [22].

Rising atmospheric $\mathrm{CO}_{2}$ often triggers the production of plant phenolics [23]. However, it was recently shown that high $\mathrm{CO}_{2}$ and low $\mathrm{pH}$ conditions due to ocean acidification decrease, rather than increase, concentrations of phenolic protective substances in seagrasses and eurysaline marine plants. These responses are different from those exhibited by terrestrial plants. The loss of phenolic substances may explain the higher-than-usual rates of grazing observed near undersea $\mathrm{CO}_{2}$ vents and suggests that ocean acidification may alter coastal carbon fluxes by affecting rates of decomposition, grazing, and disease. These observations temper recent predictions that seagrasses would necessarily be "winners" in a high $\mathrm{CO}_{2}$ world [24].

Another aspect to be handled by marine plant organisms is the water and solute transport within the whole organism. By using apoplastic tracers, Barnabas [25] showed that sea water freely enters from the medium and moves amongst the leaf blade and root tissues of Thalassodendron ciliatum and Halodule uninervis. However, water movement is restricted by the suberin of the vascular bundles in the blades and by the hypodermis and endodermis in the roots. Suberin is often deposited as lamellae, either throughout the entire wall or concentrated into bands in the radial walls (i.e., Casparian strips). In leaves of the seagrass Thalassodendron ciliatum suberin is found throughout the cell wall and in the middle lamella between contiguous bundle sheath cells [25]. Furthermore, in contrast to leaf blades, leaf sheaths have a distinct "suberin-like" cuticle that prevents seawater from entering the sheath tissue and acts as a protection of the meristem tissues and developing leaves. Also in the root hypodermis Casparian band-like structures were detected in several seagrass genera (Zostera, Halophila), but not in other submersed species such as Egeria densa, Eichhornia crassipes, and Lemna minor. These bands contained suberin and had an ultrastructure resembling Casparian bands of the endodermis. They blocked apoplastic transport into the interior tissues of the roots. Symplastic transport through the root tissues was not affected by the bands' presence [26]. Therefore, controlled selective transport of ions and water in the presence of osmolytic compounds can be well reconstructed.

Oxygen transport creates another problem for marine (and freshwater) plants due to its low solubility in water. In seagrasses, oxygen is transported to rhizomes and roots of seagrasses during periods of light when photosynthesis releases oxygen into aerenchyma. This kind of tissue is present in all seagrass species to different extents and forms large internal gas spaces [17]. Also air-spaces have been described in below-ground tissues. Around the roots an oxidized zone is formed and oxygen diffuses into the anoxic sediment. By night almost all oxygen transport stops and alcoholic fermentation starts in roots [27]. The oxygenated rhizosphere of seagrasses during photosynthesis might create a special environment for the uptake of limiting nutrients with the help of nutrient/metal-binding and the detoxification of toxic elements by oxygenation and/or binding to chelating compounds. Seagrasses have roots and vascular tissue allowing them to absorb and translocate nutrients from soft sediment. In low nutrient environments this provides seagrass with a competitive advantage over algae as they can access the higher nutrient concentrations available in the sediment compared to the overlying water. On the other hand, in contaminated sediments seagrasses need good strategies to avoid accumulation of toxic compounds in their tissue (see Section 5.6).

Roots and stems of seagrasses trap organic matter and sediment. The decaying organic matter produces a lot of toxic sulfide. So far it was assumed that the amount of oxygen released from the roots is sufficient to detoxify the high amounts of sulfide, and stated therefore another problem successfully solved by seagrasses. However, in most seagrass beds ancient three-stage symbiosis between seagrass (Zostera noltii), lucinid bivalves (Loripes lacteus), and their sulfideoxidizing gill bacteria reduces sulfide stress for seagrasses. The bivalve-sulfide-oxidizer symbiosis reduces sulfide levels and enhances seagrass production as measured in biomass. In turn, the bivalves and their endosymbionts profit from organic matter accumulation and radial oxygen release from the seagrass roots [28]. Therefore, symbiotic and other types of biotic interactions with organisms also have to be kept in mind when investigating the physiology of seagrasses in the future.

There are still many open questions in seagrass physiology, and therefore more physiological studies are needed to solve the basic problem how they deal with salinity both in seagrasses and in euryhaline aquatics [6]. One reason for the lack of knowledge is the establishment of suitable culturing conditions, a prerequisite for doing reproducible physiological experiments with a sufficient number of repetitions. Culturing of seagrasses is accompanied by a number of difficulties: when grown in climatic chambers using natural sediment, artificial seawater, and high sodium vapor lamps, the temperature needs to be carefully controlled and still the light intensity is rather low inside the water basins. Also artificial seawater does not completely mimic natural seawater conditions producing suboptimal growth or even stress conditions.

More recent approaches also include high throughput methods such as transcriptomics to analyze the responses of seagrasses, at least on the expression level [7]. The resulting EST data are publicly available (Dr. ZOMPO, http://drzompo .uni-muenster.de/) and are very helpful to design comprehensive studies on certain aspects of seagrass physiology. 
If these data are combined with metabolomic data we will be able to learn more about the hidden details of seagrass physiology. These approaches will also be speeded up because the complete genome of Zostera marina is currently being sequenced and will be published within the next year (http:// www.jgi.doe.gov/sequencing/why/Zmarina.html).

4.2. Role of Aquaporines in Seagrasses. Terrestrial plants depend on water supply for their growth and development, and constantly absorb and lose water. The diffusion of water can be driven by concentration gradients of osmotically active solutes or by physical pressure, generating an osmotic or hydrostatic force, respectively. Beyond simple diffusion across a lipid bilayer, the existence of proteinaceous water channels, aquaporins, in plant membranes has been established [29]. While studying mechanisms involved in water transport in marine plants, two aquaporin-encoding genes, PoPIP1; 1 and PoTIP1; 1, were isolated from Posidonia oceanica showing high similarity to plasma membraneand tonoplast-intrinsic protein-encoding genes, respectively. Hyposalinity induced lower levels of PIP1 transcripts, while hypersalinity determined more PIP1 transcripts than normal salinity. TIP1 transcripts increased in response to both hypo- and hypersalinity after two days of treatment and decreased to control levels after $5 \mathrm{~d}$ [30]. The expression was also investigated by in situ hybridization [31]. PoPIP; 1 transcript was associated with the meristematic region of the apical meristems (shoot and root), whereas the PoTIP; 1 was mainly associated with the tissues showing a welldifferentiated vacuole compartment. Moreover, PoPIP; 1 intensively marked the epidermal and subepidermal cells in the leaves and also in the provascular and vascular tissues. After hypersalinity treatment, the PoTIP; 1 tissue expression strongly increased compared to that of PoPIP; 1 . In contrast to terrestrial plants, where aquaporins are involved in water transport, these in situ results suggest a role in the water balance and/or solute transport in the different organs and tissues of Posidonia oceanica.

\section{Striking Metabolites}

5.1. General Introduction. Due to their convergent evolution, seagrasses share a number of analogous acquired metabolic adaptations. But their secondary metabolism varies among the four families that can be considered as true seagrasses. Terrestrial-like species returned to the sea, during the period of the ancient Tethys Sea, surrounded by Africa, Gondwanaland, and Asia, approximately 90 million years ago, thus explaining the "terrestrial-like" chemical profile of the seagrass. Several types of secondary metabolites have been studied in seagrasses, often from a chemotaxonomic viewpoint. Attaway et al. [32] found that the normal alkanes of several genera represented less than $0.01 \%$ dry weight but their distribution paralleled current taxonomic schemes of the seagrasses, with Halodule and Syringodium distinguished from each other and even more clearly from Thalassia and Halophila. Cluster analysis of high resolution GC-MS analyses of the sterols and fatty acids of a number of species from tropical Australia [33] also confirmed significant segregation of the genera Cymodocea and Halodule from the hydrocharitacean genera Thalassia and Enhalus. However, Halophila, a genus from the latter family, but with very different morphology, was separated at a much higher level from all the other seagrasses analyzed. Taxonomic questions at the species level in seagrasses have also been approached chemically by McMillan et al. [34, 35] using secondary products such as the flavonones and their sulfated derivatives from Amphibolis, Halodule, Halophila, Posidonia, and Zostera. Thus identification of evolutionary unique phytochemicals may elucidate the taxonomic relationships beside existing DNA-based approaches. Chemotaxonomy is not the main criterion to analyze secondary compounds of seagrasses but researchers hope to find new chemical structures of natural compounds which might be used in a different application. Advanced techniques such as LS-MS (MS), GS-MS, and NMR now available to more research groups simplify the analysis of secondary compounds in seagrasses. As recently shown by Wissler et al. [7], phylogenetically interesting genes could be identified by comparing the transcriptional pattern of Posidonia oceanica and Zostera marina. Transcriptomics combined with metabolomic studies might help to elucidate seagrass-specific metabolomic pathways.

\subsection{Phenols in Seagrasses}

5.2.1. Occurrence of Phenolic Acids in Seagrasses. The secondary metabolism of seagrasses shares features like the absence of hydrolysable tannins [36]. By taking a rough look at their metabolism, the basic pool of secondary metabolites is similar to their terrestrial relatives from which they have evolved. However, while comparing the variability of single pathways, for example, of the phenolic substances, Vergeer et al. [37] observed that seagrasses can be considered as a rich source for those, including phenolic acids, sulfated phenolic acids, flavones, condensed tannins, and also lignins. The pathways for the production of the huge variability of phenol derivates are interesting from an evolutionary point of view (unpublished own data). The changes in phenol metabolism are the result of continuous evolution: by gene duplication, mutation, subsequent recruitment, and adaptation to specific functions [38]. This reflects the adaption to the marine environment. But some compounds are exclusively found in single seagrass families or species, such as zosteric acid [39]. Some phenolic compounds were isolated from Zostera marina and suggested to have an important role in inhibition of microbial growth, amphipod grazing and in the resistance to the so-called waste-disease [40]. The fact that these crude methanolic extracts of Zostera marina have been found to inhibit the attachment of marine bacteria, diatoms, barnacles, and polychaetes on artificial surfaces suggests an antifouling potential of Zostera marina phenolic compounds. The $p$-(sulfooxy) cinnamic acid (zosteric acid) was isolated for the first time as a natural product from the seagrass Zostera marina and was found to prevent attachment of marine bacteria and barnacles to artificial surfaces at nontoxic concentrations [39].

Gallic acid is synthesized and stored in more than $50 \%$ of all seagrass species [41]. Also differences in the 
biosynthesis of phenolic acids can be expected in the different seagrass families. Zosteric acid for example is a hydroxy cinnamic acid derivative, whereas other phenolic acids are caffeic acid derivatives [42]. The occurrence of the sulfated phenolic compounds indicated subgeneric differences in Zostera and interspecific differences in Halophila [43]. It would be interesting to investigate the biosynthesis of zosteric acid in Zostera genera to analyze the biosynthetic enzymes in the pathway. In a patent (http://www.patentgenius.com/patent/6841718.html) a specific sulfotransferase was suggested to be involved. However, no prove was shown to verify the assumption. Harborne and Williams [42] indicated the presence of sulfated flavones in Halophila, Thalassia, and Zostera species, but they were not recorded in Syringodium or Posidonia.

At least 23 phenolic compounds were identified in the seagrass Posidonia oceanica [44]. Chicoric acid and caftaric acid were identified in detrital and living leaves of the tropical seagrass Syringodium filiforme making this abundant renewable raw material of interest for pharmaceutical purposes and food industries [45]. Phytochemical investigations revealed the presence of unidentified sulfated phenolic compounds from nine different species of Halophila [43], unidentified sulfated and nonsulfated flavones from the Halophila ovalis/Halophila minor complex [35], flavones and flavone glycosides from Halophila johnsonii [46], as well as malonylated flavonoid derivatives in the seagrass Halophila stipulacea [47]. Production of phenolic compounds depends on the environmental conditions. For example, tannin production can be wound-induced in Thalassia testudinum under simulated grazing conditions [48], and the content of phenolic compounds in shoots of Zostera marina varied seasonally [49]. The concentration of phenolic compounds was measured in the seagrass Posidonia oceanica when interacting with two Bryopsidophyceae, Caulerpa taxifolia, and Caulerpa racemosa. Several phenolic compounds were identified in Posidonia oceanica, with a predominance of caffeic acid in the adult and intermediate leaves. The number of tannin cells, which are assumed to produce the phenolic compounds, increased in the leaves when the degree of interaction with Caulerpa taxifolia increased. Therefore, interaction of Caulerpa taxifolia with the seagrass Posidonia oceanica induces its production of secondary metabolites, probably to limit the invasion of the beds [50].

5.2.2. Polyphenols: Lignin Content and Biosynthesis. One might assume that seagrasses do not contain any lignin because they are supported by the hydraulic forces of the water body. However, in all species analyzed so far lignin was detected in several tissue types and several isoblastic cells. Species variation of the lignin content is dependent on the morphotype and life style of the seagrass. Posidonia oceanica contains more lignin than Zostera marina, and roots and rhizomes generally contain more lignin than leaves. Obviously, the ability to produce lignin is not lost by the angiosperm ancestors of extant seagrasses upon their colonization of the marine environment. Relative lignin abundances in the different tissues appear to be positively correlated with life span. Lignification seems to contribute to the longevity of a tissue by protecting it against microbial attack, and deposition of lignin in seagrasses is restricted to tissues that show limited growth [51]. The importance of lignin in making seagrass below-ground organs particularly decayresistant still needs to be adequately addressed as well as their role as carbon sink. In comparison to lower plants species the seagrass Posidonia oceanica shows a broad variability in lignin composition but rather low total lignin content in purified cell walls [52]. The increased heterogeneity of lignin monomer composition might be related to the separation of water transport and support functions, although it has been reported that the presence of syringyl lignin is not necessarily linked to the presence of xylem vessels [53, 54]. Recent data imply that lignification originated as a developmental enabler in the peripheral tissues of protracheophytes and would only later have been coopted for the strengthening of tracheids in eutracheophytes [52]. A pilot study of thermallyassisted hydrolysis and methylation with pyrolysis GC-MS for the analysis of vegetable fibres in forensic science found that the fibre types tended to group into two clusters, with one containing cotton, hemp, and linen; and the other consisting of hessian, sisal, jute, and coir. The fibres of a seagrass sample differed from both groups [55].

Lignins arise from the peroxidase-mediated coupling of $p$-coumaryl, coniferyl, and sinapyl alcohols. In gymnosperms, they are derived from coniferyl alcohol, whereas in angiosperms, lignins are derived from coniferyl and sinapyl alcohols. Until recently, most peroxidases characterized in flowering plants only oxidized coniferyl alcohol. However, recent reports have described the molecular characterization of peroxidases capable of oxidizing sinapyl alcohol (syringyl peroxidases) [56]. Class III peroxidases are members of a large multigene family, only detected in the plant kingdom and absent from green algae sensu stricto (chlorophyte algae or Chlorophyta). Their evolution is thought to be related to the emergence of the land plants. However, class III peroxidases are present in a lower copy number in some basal Streptophytes (Charophyceae), which predate land colonization. Current molecular studies propose that the structural motifs of syringyl peroxidases predate the radiation of tracheophytes, which suggests that syringyl peroxidases existed before the appearance of syringyl lignins [56]. Their high copy number, as well as their conservation could be related to plant complexity and adaptation to increasing stresses. Probably subfunctionalization explains the existence of the different isoforms [57]. In Arabidopsis thaliana 73 class III peroxidase genes were clustered in robust similarity groups. Comparison to peroxidases from other angiosperms showed that the diversity observed in Arabidopsis preceded the radiation of dicots, whereas some clusters were absent from grasses. Grasses contained some unique peroxidase clusters not seen in dicot plants [58]. The distribution of lignin in the seagrass plant needs to be investigated in more detail. Own microscopical studies using different staining techniques indicate the abundance of different types and numbers of idioblastic lignified cells along the leaf tissue. Their function is so far unknown [59]. 
5.2.3. Abundance of Flavonoids. The polyphenolic flavonoids are found in either of five chemical structures, like flavones, flavonols, flavanons, flavanols, and anthocyanidins. The presence of sulfated flavones was reported in Halophila, Thalassia, and Zostera species, but they were not recorded in Syringodium spp. or Posidonia oceanica [42]. Flavonoid sulfates were also detected in Halophila ovalis and Thalassia testudinum [43, 60]. McMillan et al. [43] extensively studied 43 species of seagrasses and showed that all contained either flavones and/or phenolic acid sulfates. The occurrence of the sulfated phenolic compounds indicated subgeneric differences in Zostera and interspecific differences in Halophila.

One example demonstrates the antifouling effect of sulfated flavonoides. Significantly fewer thraustochytrid protists (zoosporic fungi) were observed in association with healthy leaf tissue of Thalassia testudinum than in association with sterilized samples that were returned to the collection site for $48 \mathrm{~h}$. In support of the hypothesis that seagrass secondary metabolites were responsible for these differences, extracts of healthy Thalassia testudinum leaf tissues inhibited the growth of the cooccurring thraustochytrid Schizochytrium aggregatum and deterred the attachment of Schizochytrium aggregatum motile zoospores to an extract-impregnated substrate. By using Schizochytrium aggregatum for bioassayguided chemical fractionation, luteolin was isolated. These results offered the first complete chemical characterization of a sulfated flavone glycoside from seagrasses and provide evidence that a secondary metabolite chemically defends Thalassia testudinum against fouling microorganisms [61]. The four flavones, luteolin, apigenin, luteolin3-glucoronide, and luteolin-4-O-glucoronide, all of them with antibicrobial potential were identified from the ethanol extract of air-dried Enhalus acoroides from South China Sea [62].

Cannac et al. [63] reported flavonoid glycosides and acyl derivatives, which yield after hydrolysis the respective flavonoid aglycones in Posidonia oceanica leaves. Later, Cannac et al. [64] found dramatic losses of flavonoids when analyzing freeze-dried and chilled leaves as opposite to fresh and oven-dried leaves of Posidonia oceanica. Bitam et al. [47] isolated and identified malonylated flavone glycoside derivatives from Halophila stipulacea using HPLC and NMR. Heglmeier and Zidorn [4] compiled and appraised the data of secondary metabolites of Posidonia oceanica and they summarized 51 natural products including phenols, phenylmethane, phenylethane, phenylpropane derivatives and their esters, chalkones, and flavonoids. Significantly higher flavonoid amounts were observed in the leaves of intertidal and subtidal Halophila johnsonii when compared to the leaves of intertidal Halophila decipiens [65]. These functional derivatives of flavonoids are considered to strive against the marine microorganisms exhibiting chemical defense. Takagi et al. [66] identified next to phenols including phenolic acids, lignin and flavonoids, and isoprenoids, also alkaloids in Phyllospadix iwatensis. This newly identified flavonoidal alkaloid was called phyllospadin. However, the class of alkaloids is not well represented in the four seagrass families.
5.3. Terpenoids. There is only one detailed report on the occurrence of terpenoids in seagrasses. Despite the important ecological role of Cymodocea nodosa in the marine ecosystem, knowledge of its chemical content is limited. Only molecules frequently found in terrestrial plants such as caffeic acid, inositol, sucrose, monoglucoside of quercetin, monoglucoside of isoramnetin, cichoric acid, as well as polyamines like putrescine, spermidine, and spermine, have been reported as constituents of Cymodocea nodosa. Furthermore, 24a-ethyl sterols and 24a-methyl sterols along with their 24b-epimers, cymodiene and cymodienol, the first diarylheptanoids isolated from marine organisms, comprise the total number of metabolites isolated from Cymodocea nodosa so far. Recently, new terpenoid compounds from the structural class of diarylheptanoids, a new meroterpenoid, and the first briarane diterpene isolated from seagrass, and only the second analog of this class with a tricyclic skeleton. Furthermore this metabolite is the first brominated briarane diterpene [67]. All newly detected compounds were assayed for their antibacterial activity against multidrug resistant (MDR) and methicillin-resistant bacterial strains. The activity reached from weak to strong and therefore opens the field for the formulation of new antibiotics [67] which are urgently needed due the many MDR strains, especially in hospitals. Probably more compounds with antibiotic activity in seagrasses will be found.

\subsection{Sugars and Sulfated Polysaccharides in Seagrasses}

5.4.1. Remarkable Sugars. The osmoregulation in seagrasses has not been unambiguously elucidated so far. Several sugars might play a role. The sugar chemistry of seagrasses evolved differently from land plants, leading to a broad range of different inositols in addition to the ubiquitous sucrose, glucose, and fructose [68]. Of the nine possible inositols, five are known to occur in plants; myo-, l-chiro-, muco- and O-methyl-mucoinositol occur in seagrasses. Myo-inositol is found in all living cells in amounts usually considerably less than $1 \%$ dry weight. It is apparently synthesized by direct cyclization of photosynthetically-produced glucose and it is mainly used in cell wall synthesis. Leaves and rhizomes of some seagrasses, particularly the Zosteraceae, contain relatively large amounts of this compound, up to a maximum of $2.2 \%$ dry weight in Zostera noltii rhizomes. In most plants the cyclization enzyme is conservative and yields only myoinositol, which then acts as the sole precursor for any other inositols they accumulate. Drew $[68,69]$ suggested that, since the configuration of the glucose molecule would permit the direct formation during cyclization of all the inositols found in seagrasses, they may be inevitable byproducts of another, less specific, glucose cyclization enzyme.

Taking this as a base, Drew [68] tried to solve the phylogeny of seagrasses, according to the inositol pattern, taking the genus Halodule as common ancestor. Only members of Cymodoceaceae accumulate these other inositols, with a preponderance of l-chiro-inositol. This compound has been detected in all genera except Halodule, with a maximum of $6.8 \%$ dry weight in Cymodocea rotundata leaves. Mucoinositol appears to be slightly less widely distributed in these 
seagrasses whilst its O-methyl ester is restricted to the endemic temperate Australian genus Amphibolis. However, those other than myo-inositol can probably accumulate to several percent dry weights because they are not subsequently utilized, even after all soluble sugars have been respired away during dark starvation for several days. The possibility that these compounds might be involved in an osmoregulatory role was not supported by studies at high and low salinities, although respiration, and therefore sucrose utilization, was increased at both extremes [68]. Tyerman et al. [70] also implicated sucrose, and possibly amino acids, as minor osmoregulants, in their study of the osmotic environment of Posidonia australis and Zostera capricorni leaves.

5.4.2. Sulfated Polysaccharides. Sulfated polysaccharides (SPs) comprise a complex group of macromolecules with a wide range of biological, partly unknown functions. These anionic polymers are widespread in nature, occurring in a large variety of organisms. Although their structures vary among species, their main features are conserved among phyla. Green algal SPs are quite heterogeneous and usually heteropolysaccharides. The red algal SPs (like agar and carrageen) are composed of repeating disaccharide units with different sulfation patterns which vary among species. The SPs from invertebrates such as sea urchins and ascidians (tunicates) are composed of well-defined repetitive units. Chains of 3 -linked $\beta$-galactoses are highly conserved in some marine taxonomic groups, with a strong tendency toward 4-sulfation in algae and marine angiosperm, and 2-sulfation in invertebrates [71]. SPs of seagrass species are composed of galactose units. Seagrass species contain various amounts dependent on the organ and on the salinity (Halodule wrightii $8.5 \mu \mathrm{g}$ SP and Halophila decipiens $7.7 \mu \mathrm{g}$ SP per mg dry weight), comparably high as some mangrove species, whereas in terrestrial crop plants the values are below $0.001 \mu \mathrm{g}$ SP per mg dry weight $[72,73]$.

So far SP biosynthesis and exact physiological role in seagrasses were not clarified. Probably the biosynthesis of sulfated galactans starts with a precursor of lower molecular weight and degree of sulfation suggesting that glycosyltransferases and sulfotransferases may function simultaneously during the biosynthesis of sulfated galactans, at least in $R$. maritima [73]. Until the first seagrass genome will be completely sequenced, the identification of responsible glycosyltransferases and sulfotransferases using the sequenced genome of Ectocarpus siliculosus [74] might be a promising approach. Interestingly, green algae, the ancestor of higher plants [75], possess all units of SP also found in all investigated halophytic aquatic plants $[72,73]$. This finding suggests that the production of SP is conserved throughout the plant evolution from green algae [73]. It is speculated that the activation and inhibition of glycosyltransferase genes alter the composition of SP among the different phyla [73].

In seaweeds, SPs are found in the extracellular matrix. SP might protect against dehydration occurring at low tide. They are important both in terms of resistance to mechanical stresses and as protection from predators [76]. The function of SP in the plant cell wall in high salt environments is still unclear. It is speculated that SPs increase the Donnan potential [77], supporting ion transport at high salt concentrations. In Ruppia maritima SPs were not found when the plant was cultivated in freshwater [73]. Species being able to survive in both saline and freshwater conditions might be well-suited study objects to analyze the function of SP. The current state of knowledge suggests that the presence of SP in plants is an adaptation to high salt environments, which have been conserved during plant evolution from marine green algae.

5.5. Dimethylsulfoniopropionate (DMSP) in Seagrass. It was shown that next to green, red, and brown algae several angiosperms produce dimethylsulfoniopropionate (DMSP). DMSP is broken down by marine microbes to form two major volatile sulfur products, each with distinct effects on the environment. Its major breakdown product is methanethiol which is assimilated by bacteria into protein sulfur. Its second volatile breakdown product is dimethyl sulfide (DMS). Atmospheric oxidation of DMS, particularly sulfate and methanesulfonic acid, is important in the formation of aerosols in the lower atmosphere. Probably these aerosols act as cloud nucleation sites. Therefore DMS is thought to play a role in the Earth's heat budget by decreasing the amount of solar radiation that reaches the Earth's surface [78].

However, the presence of high concentrations of DMSP in higher plants is limited to a few species such as Spartina spp. (>50 $\mu \mathrm{mol} \mathrm{DMSP} \mathrm{g}{ }^{-1}$ fresh weight in the leaves) [79]. In seagrasses different DMSP concentrations have been found: Halodule wrightii $3.3 \mu \mathrm{mol} \mathrm{g}^{-1}$ fresh weight, Syringodium filiforme $0.10 \mu \mathrm{mol} \mathrm{g}^{-1}$ fresh weight, Thalassia testudinum in epiphytized and nonepiphytized leaves between 0.18 and $4.0 \mu \mathrm{mol} \mathrm{g}^{-1}$ fresh weight, and very low amounts in the rhizome [80]. These results indicate that the degree of epiphytization plays a major role in the contribution of seagrasses to the total DMSP production. The regulation of the biosynthetic pathway of DMSP in seagrasses needs to be elucidated to clarify the overall contribution by seagrasses.

5.6. Peptides and Proteins Involved in Metal Binding. Heavy metals are taken up by seagrasses and accumulate in different tissues to different extents [81-83]. Several seagrass species such as Posidonia oceanica [84], Cymodocea nodosa [85], Cymodocea spp., Enhalus acoroides, Halodule spp., Halophila spp., Syringodium isoetifolium, and Thalassia hemprichii [83, $86,87]$ have been even used as bioindicator for heavy metal accumulation in contaminated and noncontaminated areas. It was shown that the accumulation of the same metal varies by different species of seagrasses and heavy metals were not homogeneously distributed in all the seagrasses [87]. Also Thalassia testudinum was used as bioindicator for trace metal stress and investigated in more detail. For this species, the accumulation of $\mathrm{Cd}$ varied in a dosedependent manner and according to the tissue examined. $\mathrm{Cd}$ accumulation of green leaves was higher than other organs (sheaths, roots/rhizomes) after $96 \mathrm{~h}$ of treatment. It was found that the higher the Cd concentration in ambient environment the higher the Cd concentration in the tissue. 
Besides significant different $\mathrm{Cd}$ accumulation in different tissues, results also showed that thiols including cysteine, glutathione and $\gamma$-glutamylcysteine, and phytochelatin-(PC-) like peptides were induced after different times of exposure. Thiols were found in the green blades and rhizomes after $24 \mathrm{~h}$ of treatment, whereas in the sheaths those thiols accumulated after $114 \mathrm{~h}$ of exposure. Moreover, total thiols in green blade tissue showed the highest content, followed by live sheaths and root/rhizome [88].

PCs and metallothioneins (MTs) are Cys-rich metal chelators that represent the two principle groups of metalbinding molecules found across most taxonomic groups [89]. PCs, glutathione-derived metal binding peptides, usually with the structure of $\left(1^{\prime} \text {-Glu-Cys }\right)_{n}$-Gly $(n=2-11)$ are enzymatically synthesized peptides known to be involved in heavy metal detoxification, mainly $\mathrm{Cd}$ and As, which has been demonstrated in plants, algae, and some yeast species grown at high heavy metal concentrations [90]. So far, neither the exact composition of PCs in seagrasses nor the biosynthetic enzyme, PC synthase, have been analyzed in seagrasses.

MTs are a group of proteins with low molecular mass and high cysteine content that bind heavy metals and are thought to play a role in their metabolism and detoxification [90]. The criteria that define a protein or peptide as an MT are (i) low molecular weight $(<10 \mathrm{kDa})$, (ii) high metal and sulfur content $(>10 \%)$, (iii) spectroscopic features typical of $\mathrm{M}-\mathrm{S}$ bonds, and (iv) absence or scarcity of aromatic amino acids [91]. However, when all criteria are not fulfilled often proteins are called MT-like proteins. There are only a few papers reporting on the metal-binding mechanisms of seagrasses $[92,93]$. Three genomic sequences putatively encoding MTs were isolated from Posidonia oceanica [92], namely, Pomt2a, Pomt $2 b$ and Pomt $2 c$ that showed high similarities to putative plants MTs. Pomt2a and Pomt $2 b$ contain a CXXC motif classifying them as type II plant MTs, the remaining Pomt $2 c$ is considered to be a pseudogene. Moreover, authors indicated that there were at least five MT genes present in Posidonia oceanica genome based on Southern blot hybridizations. Results of Giordani et al. [92] showed that based on Northern blot hybridization MT transcript accumulation was increased by $\mathrm{Cu}$ and $\mathrm{Cd}$ exposure, whereas no apparent effect was observed after $\mathrm{Hg}$ treatment. Higher $\mathrm{Cu}^{2+}$ concentration $(10 \mu \mathrm{mol})$ treatment showed higher MT transcript accumulation than low $\mathrm{Cu}^{2+}$ concentration $(1 \mu \mathrm{mol})$. Based on these results Cozza et al. [93] continued to carry out the studies in more detail. Nine MT-like sequences from $\mathrm{Cu}$ or $\mathrm{Cd}$ treated Posidonia oceanica were isolated by RT-PCR. One sequence is similar to Pomt $2 b$. Phylogenetic analysis of MT-like protein deduced from isolated MT-encoding genes from Posidonia oceanica showed two subgroups. To better understand the functional role of the two MT subgroups one gene representative for each group was used for in situ hybridization to discover spatial expression of the plant. Interestingly, the members of these two MT subgroups showed differences in their histological expression, with Pom $2 b$ associated with the proliferative tissues whereas Pomt $f f$ was associated with the lignified or suberized cell wall [93].
In summary, seagrasses can survive and grow well in environments contaminated with heavy metals. On the one hand, putative MT-like proteins are considered to bind heavy metals. On the other hand, the dominant frequency of putative MT transcripts found in Zostera marina under heat stress suggests that other functions of MTs are still unknown. Hence, detailed research on MT function and the number of genes encoding MTs are needed.

\section{Economical Use of Seagrasses and Their Products}

6.1. Technical Applications. Studies reveal the importance of the seagrass Zostera marina for subsistence cultures for many generations, for example, in the North Atlantic [94]. These cultures derive many and varied natural products from this plant species and their recognized historical value contributes to the protection of sites of former gathering activity [94]. Ethical positions regarding the value of resource extraction are common among traditional and indigenous cultures, often leading to the protection of habitats that support valuable resources. Also in Europe the dried flotsam of Zostera marina was used as mattrass and padding material, as erosion protection mat and for insulation at the end of the 19th and beginning of the 20th century. Since a few years Zostera flotsam is used to press flake boards for insulation purposes (http://tu-dresden.de/ Members/soeren.tech/news/Seegras).

Intensive elder literature including ethnobotanical observations and screening of more recent literature revealed many inhibitory activities of seagrass material. Crude extracts showed antibacterial, antifungal, antiviral, antioxidant, antiinflammatory, antidiabetic, anti-cancerogen, and so forth activities. In some studies the researchers aimed to identify and isolate the bioactive compound in the extracts. Fractionation and isolation of compounds by HPLC analysis were partly successful. There are several examples of successful demonstration of bioactive activity of a single compound. One very successful case study is the structure determination of zosteric acid, its subsequent chemical synthesis, and the exploration of its biotechnological applications. This discovery followed the general approach shown in Figure 2.

It was observed that rates of decomposition (usually $<1 \%$ of dry weight day $^{-1}$ ) of Zostera flotsam are generally low compared with other vascular macrophyte sources of detritus, but are influenced by many variables. Seagrass detritus undergoes an initial period of leaching, leaving a poor substrate for bacteria because what soluble material remains is deficient in inorganic nutrients, contains inhibitory phenolic compounds, and is protected by cellulose and lignin $[49,95]$. One inhibitory compound is zosteric acid (Figure 3) [39].

Recently, zosteric acid was generated by treating trans4-hydroxycinnamic acid with the sulfur trioxide pyridine complex, a solid, easy to handle compound, in N,Ndimethylformamide (DMF) as solvent. After $2 \mathrm{~h}$ at $50^{\circ} \mathrm{C}$, trans-4-hydroxycinnamic acid is completely converted to zosteric acid. The latter was isolated as the sodium salt by 


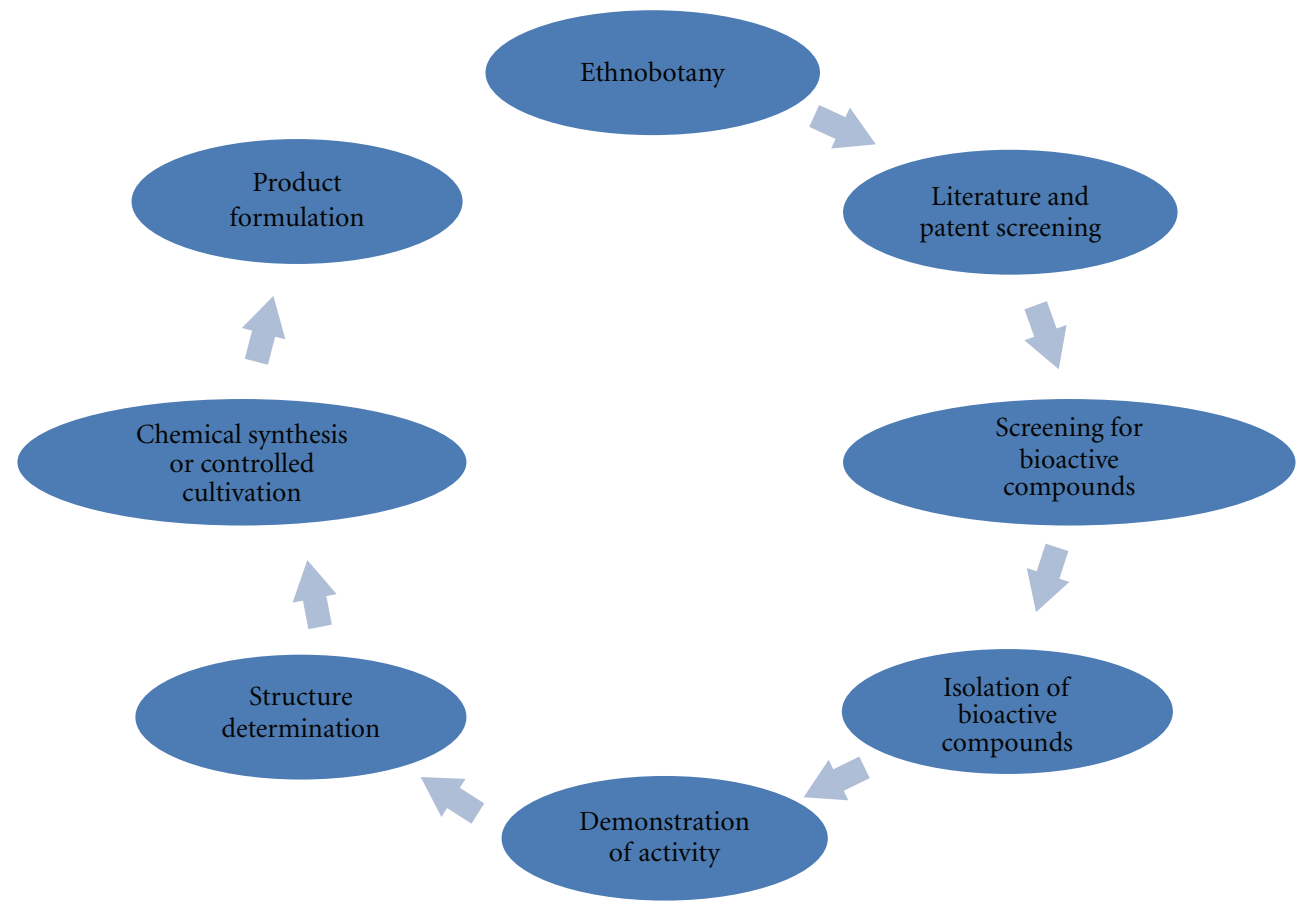

FIGURE 2: General approach from the identification to the application of secondary compounds of economic value.<smiles>O=C(O)/C=C/c1ccc(OS(=O)(=O)O)cc1</smiles>

FIGURE 3: Chemical structure of zosteric acid.

adding $30 \% \mathrm{NaOH}$ to $\mathrm{pH} 7$, followed by extraction with dichloromethane to remove pyridine and DMF [96].

Based on this relatively simple synthesis large amounts of zosteric acid can be produced. Currently, its biofilm inhibiting activity is tested by different research groups. The antifouling effectiveness of zosteric acid has been demonstrated both in static laboratory assays and with zosteric acid directly dispersed in marine water [97]. With respect to the mode of action, it was shown that zosteric acid hinders the biofilm formation by increasing the bacterial motility by $40 \%$. Therefore the phase from the planktonic life form to the sessile by attachment to the surface does not take place [96]. Zosteric acid seems to be an ideal compound because it has low general toxicity but specifically inhibits biofilm formation at early stages. Product development and zosteric acid formulation is underway, for example as an ingredient in antifouling paints. Probably, there will be more compounds isolated from seagrasses with antifouling activity because there are a number of publications reporting inhibition of biofilm formation, such as methanolic extracts of Cymodocea rotundata accessions collected in the Gulf of Mannar, India [98].
6.2. Pharmaceutical and Nutraceutical Applications. One of the rare real applications seems to be zosterin, a bioactive pectin from Zostera asiatica, which decreases toxicity of antitumor drugs and purges heavy metals from human organisms [99]. These properties led to a patented and marketed drug and food in Russia (Patents RU2128918, RU2129388C1, RU2132696C1, and RU2242217).

It is suggested to use extracts of Zostera marina as a material for cosmetics (Patent EP1342468 B1, New cosmetic raw materials from plants of the family Zosteraceae for special cosmetic effects and uses. The use is claimed for the topical cosmetic use of biologically-active ingredients from extracts, seaweed hyaluronates and micropowder obtained from Zosteraceae plants by solvent treatment) and pharmaceutical applications (Patent EP 1338286 A1 Use of extracts from plants of the family Zosteraceae for the prevention and therapy of bacterial and viral infections).

Free L-chiro-inositol was isolated from aqueous extracts of dried detrital Syringodium filiforme leaves [100]. The high concentrations found (2.3-2.5\% dry weight) offer promise for the exploitation of Syringodium flotsam as a new cheap source for nutraceutical or therapeutic applications, considering the demonstrated hypoglycaemic action of Lchiro-inositol.

\section{Summary and Outlook}

(i) Seagrasses form an ecological group and evolved three to four times towards an aquatic and marine existence.

(ii) Seagrass taxonomy is neither solved on the species level and nor below. 
(iii) Their physiology is not well investigated due to difficult in situ and in vitro growth conditions, and there are still many adaptations to discover.

(iv) Seagrasses contain valuable compounds of economic interest not found in other taxonomic groups.

(v) Seagrass metabolite content is another still buried treasure of the ocean to be lifted.

\section{Acknowledgments}

Christina Lucas, Hannover, started the seagrass topic in our laboratory with great enthusiasm and knowledge. Her aboveaverage theoretical and practical abilities greatly speeded up the development of our seagrass projects. Thanks are also to Nguyen Xuan Vy, Hannover, who continues the phylogenetic analysis and seagrass culture with high commitment. Seagrass research in our laboratory is supported by the DAAD (Vigoni project 54644032 and A New Passage to India).

\section{References}

[1] A. W. D. Larkum, R. J. Orth, and C. M. Duarte, Seagrass: Biology, Ecology and Conservation, Springer, Dordrecht, The Netherlands, 2006.

[2] R. J. Orth, T. J. B. Carruthers, W. C. Dennison et al., "A global crisis for seagrass ecosystems," BioScience, vol. 56, no. 12, pp. 987-996, 2006.

[3] F. T. Short, B. Polidoro, S. R. Livingstone et al., "Extinction risk assessment of the world's seagrass species," Biological Conservation, vol. 144, no. 7, pp. 1961-1971, 2011.

[4] A. Heglmeier and C. Zidorn, "Secondary metabolites of Posidonia oceanica (Posidoniaceae)," Biochemical Systematics and Ecology, vol. 38, no. 5, pp. 964-970, 2010.

[5] D. H. Les, M. A. Cleland, and M. Waycott, "Phylogenetic studies in alismatidae, II: evolution of marine angiosperms (seagrasses) and hydrophily," Systematic Botany, vol. 22, no. 3, pp. 443-463, 1997.

[6] C. den Hartog and J. Kuo, "Taxonomy and biogeography of seagrasses," in Seagrass: Biology, Ecology and Conservation, A. W. D. Larkum, R. J. Orth, and C. M. Duarte, Eds., pp. 1-23, Springer, Dordrecht, The Netherlands, 2006.

[7] L. Wissler, F. M. Codõer, J. Gu et al., "Back to the sea twice: identifying candidate plant genes for molecular evolution to marine life," BMC Evolutionary Biology, vol. 11, no. 1, article $8,2011$.

[8] T. Janssen and K. Bremer, "The age of major monocot groups inferred from $800+r b c L$ sequences," Botanical Journal of the Linnean Society, vol. 146, no. 4, pp. 385-398, 2004.

[9] M. Waycott, G. Procaccini, D. H. Les, and T. Reusch, "A genetic perspective in seagrass evolution, ecology and conservation,” Springer Academic, vol. 2, pp. 25-50, 2006.

[10] J. Kuo and C. den Hartog, "Seagrass taxonomy and identification key," in Global Seagrass Research Methods, F. T. Short, C. A. Short, and R. G. Coles, Eds., vol. 33, pp. 31-58, Elsevier Science, Amsterdam, The Netherlands, 2001.

[11] M. Uchimura, E. Jean Faye, S. Shimada, T. Inoue, and Y. Nakamura, "A reassessment of Halophila species (Hydrocharitaceae) diversity with special reference to Japanese representatives," Botanica Marina, vol. 51, no. 4, pp. 258-268, 2008.

[12] F. T. Short, G. E. Moore, and K. A. Peyton, "Halophila ovalis in the Tropical Atlantic Ocean," Aquatic Botany, vol. 93, no. 3, pp. 141-146, 2010.
[13] X. Li and Z. Zhou, "Phylogenetic studies of the core Alismatales inferred from morphology and $r b c L$ sequences," Progress in Natural Science, vol. 19, no. 8, pp. 931-945, 2009.

[14] L. Y. Chen, J. M. Chen, R. Wahiti Gituru, and Q. F. Wang, "Generic phylogeny, historical biogeography and character evolution of the cosmopolitan aquatic plant family Hydrocharitaceae," BMC Evolutionary Biology, vol. 12, article 30, 2012.

[15] C. Lucas, T. Thangaradjou, and J. Papenbrock, "Development of a DNA barcoding system for seagrasses: successful but not simple," Public Library of Science ONE, vol. 7, no. 1, Article ID e35107, 2012.

[16] J. L. Olsen, W. T. Stam, J. A. Coyer et al., "North Atlantic phylogeography and large-scale population differentiation of the seagrass Zostera marina L.," Molecular Ecology, vol. 13, no. 7, pp. 1923-1941, 2004.

[17] J. Kuo and C. den Hartog, "Seagrass morphology, anatomy and ultrastructure," in Seagrass: Biology, Ecology and Conservation, A. W. D. Larkum, R. J. Orth, and C. M. Duarte, Eds., pp. 51-87, Springer, Dordrecht, The Netherlands, 2006.

[18] F. Short, T. Carruthers, W. Dennison, and M. Waycott, "Global seagrass distribution and diversity: a bioregional model," Journal of Experimental Marine Biology and Ecology, vol. 350, no. 1-2, pp. 3-20, 2007.

[19] N. Marba, M. Holmer, E. Gacia, and C. Barron, "Seagrass beds and coastal biogeochemistry," in Seagrass: Biology, Ecology and Conservation, A. W. D. Larkum, R. J. Orth, and C. M. Duarte, Eds., pp. 135-157, Springer, Dordrecht, The Netherlands, 2006.

[20] S. Beer, A. Shomer-ilan, and Y. Waisel, "Carbon metabolism in seagrasses: II. Patterns of photos ynthetic $\mathrm{CO}_{2}$ incorporation," Journal of Experimental Botany, vol. 31, no. 4, pp. 10191026, 1980.

[21] H. Frost-Christensen and K. Sand-Jensen, "The quantum efficiency of photosynthesis in macroalgae and submerged angiosperms," Oecologia, vol. 91, no. 3, pp. 377-384, 1992.

[22] J. A. Raven, A. M. Johnston, J. E. Kübler et al., "Seaweeds in cold seas: evolution and carbon acquisition," Annals of Botany, vol. 90, no. 4, pp. 525-536, 2002.

[23] P. Stiling and T. Cornelissen, "How does elevated carbon dioxide $\left(\mathrm{CO}_{2}\right)$ affect plant-herbivore interactions? A field experiment and meta-analysis of $\mathrm{CO}_{2}$-mediated changes on plant chemistry and herbivore performance," Global Change Biology, vol. 13, no. 9, pp. 1823-1842, 2007.

[24] T. Arnold, C. Mealey, H. Leahey et al., "Ocean acidification and the loss of phenolic substances in marine plants," Public Library of Science ONE, vol. 7, no. 4, Article ID e35107, 2012.

[25] A. D. Barnabas, "Apoplastic tracer studies in the leaves of a seagrass. II. Pathway into leaf veins," Aquatic Botany, vol. 35, no. 3-4, pp. 375-386, 1989.

[26] A. D. Barnabas, "Casparian band-like structures in the root hypodermis of some aquatic angiosperms," Aquatic Botany, vol. 55, no. 3, pp. 217-225, 1996.

[27] O. Pedersen, J. Borum, C. M. Duarte, and M. D. Fortes, "Oxygen dynamics in the rhizosphere of Cymodocea rotundata," Marine Ecology Progress Series, vol. 169, pp. 283-288, 1998.

[28] T. van der Heide, L. L. Govers, J. Fouw et al., "A three-stage symbiosis forms the foundation of seagrass ecosystems," Science, vol. 336, no. 6087, pp. 1432-1434, 2012.

[29] I. Johansson, M. Karlsson, U. Johanson, C. Larsson, and P. Kjellbom, "The role of aquaporins in cellular and whole plant water balance," Biochimica et Biophysica Acta, vol. 1465, no. 1-2, pp. 324-342, 2000. 
[30] P. Maestrini, T. Giordani, A. Lunardi, A. Cavallini, and L. Natali, "Isolation and expression of two aquaporin-encoding genes from the marine phanerogam Posidonia oceanica," Plant and Cell Physiology, vol. 45, no. 12, pp. 1838-1847, 2004.

[31] R. Cozza and T. Pangaro, "Tissue expression pattern of two aquaporin-encoding genes in different organs of the seagrass Posidonia oceanica," Aquatic Botany, vol. 91, no. 2, pp. 117121, 2009.

[32] D. H. Attaway, P. L. Parker, and J. A. Mears, "Normal alkanes of five coastal spermatophytes," Publications of the Institute of Marine Science, University of Texas, vol. 15, pp. 13-19, 1970.

[33] F. T. Gillan, R. W. Hogg, and E. A. Drew, "The sterol and fatty acid compositions of seven tropical seagrasses from North Queensland, Australia," Phytochemistry, vol. 23, no. 12, pp. 2817-2821, 1984.

[34] C. McMillan, S. C. Williams, L. Escobar, and O. Zapata, "Isoenzymes, secondary compounds and experimental cultures of Australian seagrasses in Halophila, Halodule, Zostera, Amphibolis and Posidonia," Australian Journal of Botany, vol. 29, pp. 247-260, 1981.

[35] C. McMillan, "Sulfated flavonoids and leaf morphology of the Halophila ovalis-H. minor complex (hydrocharitaceae) in the Pacific Islands and Australia," Aquatic Botany, vol. 16, no. 4, pp. 337-347, 1983.

[36] T. M. Arnold and N. M. Targett, "Marine tannins: the importance of a mechanistic framework for predicting ecological roles," Journal of Chemical Ecology, vol. 28, no. 10, pp. 19191934, 2002.

[37] L. H. Vergeer, T. L. Aarts, and J. D. De Groot, "The "wasting disease" and the effect of abiotic factors (light intensity, temperature, salinity) and infection with Labyrinthula zosterae on the phenolic content of Zostera marina shoots," Aquatic Botany, vol. 52, no. 1-2, pp. 35-44, 1995.

[38] M. Boudet, "Evolution and current status of research in phenolic compounds," Phytochemistry, vol. 68, no. 22-24, pp. 2722-2735, 2007.

[39] J. S. Todd, R. C. Zimmerman, P. Crews, and R. S. Alberte, "The antifouling activity of natural and synthetic phenolic acid sulphate esters," Phytochemistry, vol. 34, no. 2, pp. 401404, 1993.

[40] R. C. Quackenbush, D. Bunn, and W. Lingren, "HPLC determination of phenolic acids in the water-soluble extract of Zostera marina L. (eelgrass)," Aquatic Botany, vol. 24, no. 1, pp. 83-89, 1986.

[41] O. Zapata and C. McMillan, "Phenolic acids in seagrasses," Aquatic Botany, vol. 7, pp. 307-317, 1979.

[42] J. B. Harborne and C. A. Williams, "Occurrence of sulphated flavones and caffeic acid esters in members of the fluviales," Biochemical Systematics and Ecology, vol. 4, no. 1, pp. 37-41, 1976.

[43] C. McMillan, O. Zapata, and L. Escobar, "Sulphated phenolic compounds in seagrasses," Aquatic Botany, vol. 8, pp. 267278,1980 .

[44] S. Agostini, J. M. Desjobert, and G. Pergent, "Distribution of phenolic compounds in the seagrass Posidonia oceanica," Phytochemistry, vol. 48, no. 4, pp. 611-617, 1998.

[45] G. Nuissier, B. Rezzonico, and M. Grignon-Dubois, "Chicoric acid from Syringodium filiforme," Food Chemistry, vol. 120, no. 3, pp. 783-788, 2010.

[46] Y. Meng, A. J. Krzysiak, M. J. Durako, J. I. Kunzelman, and J. L. C. Wright, "Flavones and flavone glycosides from Halophila johnsonii," Phytochemistry, vol. 69, no. 14, pp. 2603-2608, 2008.
[47] F. Bitam, M. L. Ciavatta, M. Carbone, E. Manzo, E. Mollo, and M. Gavagnin, "Chemical analysis of flavonoid constituents of the seagrass Halophila stipulacea: first finding of malonylated derivatives in marine phanerogams," Biochemical Systematics and Ecology, vol. 38, no. 4, pp. 686-690, 2010.

[48] T. M. Arnold, C. E. Tanner, M. Rothen, and J. Bullington, "Wound-induced accumulations of condensed tannins in turtlegrass, Thalassia testudinum," Aquatic Botany, vol. 89, no. 1, pp. 27-33, 2008.

[49] P. G. Harrison, "Detrital processing in seagrass systems: a review of factors affecting decay rates, remineralization and detritivory," Aquatic Botany, vol. 35, no. 3-4, pp. 263-288, 1989.

[50] O. Dumay, J. Costa, J. M. Desjobert, and G. Pergent, "Variations in the concentration of phenolic compounds in the seagrass Posidonia oceanica under conditions of competition," Phytochemistry, vol. 65, no. 24, pp. 3211-3220, 2004.

[51] V. A. Klap, M. A. Hemminga, and J. J. Boon, "Retention of lignin in seagrasses: angiosperms that returned to the sea," Marine Ecology Progress Series, vol. 194, pp. 1-11, 2000.

[52] J. M. Espiñeira, E. Uzal, L. V. Gómez Ros et al., "Distribution of lignin monomers and the evolution of lignification among lower plants," Plant Biology, vol. 13, no. 1, pp. 59-68, 2011.

[53] Z. Jin, S. Shao, K. S. Katsumata, and K. Iiyama, "Lignin characteristics of peculiar vascular plants," Journal of Wood Science, vol. 53, no. 6, pp. 520-523, 2007.

[54] P. T. Martone, J. M. Estevez, F. Lu et al., "Discovery of lignin in seaweed reveals convergent evolution of cell-wall architecture," Current Biology, vol. 19, no. 2, pp. 169-175, 2009.

[55] R. Kristensen, S. Coulson, and A. Gordon, "THM PyGCMS of wood fragment and vegetable fibre forensic samples," Journal of Analytical and Applied Pyrolysis, vol. 86, no. 1, pp. 90-98, 2009.

[56] A. R. Barceló, L. V. G. Ros, and A. E. Carrasco, "Looking for syringyl peroxidases," Trends in Plant Science, vol. 12, no. 11, pp. 486-491, 2007.

[57] C. Mathé, A. Barre, C. Jourda, and C. Dunand, "Evolution and expression of class III peroxidases," Archives of Biochemistry and Biophysics, vol. 500, no. 1, pp. 58-65, 2010.

[58] L. Duroux and K. G. Welinder, "The peroxidase gene family in plants: a phylogenetic overview," Journal of Molecular Evolution, vol. 57, no. 4, pp. 397-407, 2003.

[59] C. Lucas, Classification and characterization of seagrass species using DNA barcoding and physiological parameters [M.S. thesis], Leibniz University Hannover, Hanover, Germany, 2011.

[60] D. C. Rowley, M. S. T. Hansen, D. Rhodes et al., "Thalassiolins A-C: new marine-derived inhibitors of HIV cDNA integrase," Bioorganic and Medicinal Chemistry, vol. 10, no. 11, pp. 3619-3625, 2002.

[61] P. R. Jensen, K. M. Jenkins, D. Porter, and W. Fenical, "Evidence that a new antibiotic flavone glycoside chemically defends the sea grass Thalassia testudinum against Zoosporic fungi," Applied and Environmental Microbiology, vol. 64, no. 4, pp. 1490-1496, 1998.

[62] S. H. Qi, S. Zhang, P. Y. Qian, and B. G. Wang, "Antifeedant, antibacterial, and antilarval compounds from the South China Sea seagrass Enhalus acoroides," Botanica Marina, vol. 51, no. 5, pp. 441-447, 2008.

[63] M. Cannac, L. Ferrat, C. Pergent-Martini, G. Pergent, and V. Pasqualini, "Effects of fish farming on flavonoids in Posidonia oceanica," Science of the Total Environment, vol. 370, no. 1, pp. 91-98, 2006. 
[64] M. Cannac, L. Ferrat, T. Barboni, G. Pergent, and V. Pasqualini, "The influence of tissue handling on the flavonoid content of the aquatic plant Posidonia oceanica," Journal of Chemical Ecology, vol. 33, no. 5, pp. 1083-1088, 2007.

[65] N. M. Gavin and M. J. Durako, "Localization and antioxidant capacity of flavonoids from intertidal and subtidal Halophila johnsonii and Halophila decipiens," Aquatic Botany, vol. 95, no. 3, pp. 242-247, 2011.

[66] M. Takagi, S. Funahashi, K. Ohta T, and T. Nakabayashi, "Phyllosadine, a new flavonoidal alkaloid from the sea-grass Phyllospadix iwatensis," Agricultural and Biological Chemistry, vol. 44, no. 12, pp. 3019-3020, 1980.

[67] I. Kontiza, M. Stavri, M. Zloh, C. Vagias, S. Gibbons, and V. Roussis, "New metabolites with antibacterial activity from the marine angiosperm Cymodocea nodosa," Tetrahedron, vol. 64, no. 8, pp. 1696-1702, 2008.

[68] E. A. Drew, "Sugars, cytolitols and seagrass phylogeny," Aquatic Botany, vol. 15, no. 4, pp. 387-408, 1983.

[69] E. A. Drew, "Factors affecting photosynthesis and its seasonal variation in the seagrasses Cymodocea nodosa (Ucria) Aschers, and Posidonia oceanica (L.) Delile in the Mediterranean," Journal of Experimental Marine Biology and Ecology, vol. 31, no. 2, pp. 173-194, 1978.

[70] S. D. Tyerman, A. I. Hatcher, R. J. West, and A. W. D. Larkum, "Posidonia australis growing in altered salinities: leaf growth, regulation of turgor and the development of osmotic gradients," Australian Journal of Plant Physiology, vol. 11, no. 1-2, pp. 35-47, 1984.

[71] V. H. Pomin, "Structural and functional insights into sulfated galactans: a systematic review," Glycoconjugate Journal, vol. 27, no. 1, pp. 1-12, 2010.

[72] R. S. Aquino, A. M. Landeira-Fernandez, A. P. Valente, L. R. Andrade, and P. A. S. Mourão, "Occurrence of sulfated galactans in marine angiosperms: evolutionary implications," Glycobiology, vol. 15, no. 1, pp. 11-20, 2005.

[73] R. S. Aquino, C. Grativol, and P. A. S. Mourão, "Rising from the sea: correlations between sulfated polysaccharides and salinity in plants," PLoS ONE, vol. 6, no. 4, Article ID e18862, 2011.

[74] G. Michel, T. Tonon, D. Scornet, J. M. Cock, and B. Kloareg, "The cell wall polysaccharide metabolism of the brown alga Ectocarpus siliculosus. Insights into the evolution of extracellular matrix polysaccharides in Eukaryotes," New Phytologist, vol. 188, no. 1, pp. 82-97, 2010.

[75] L. A. Lewis and R. M. McCourt, "Green algae and the origin of land plants," American Journal of Botany, vol. 91, no. 10, pp. 1535-1556, 2004.

[76] J. M. Cock, L. Sterck, P. Rouzé et al., “The Ectocarpus genome and the independent evolution of multicellularity in brown algae," Nature, vol. 465, pp. 617-621, 2010.

[77] F. G. Donnan, “The theory of membrane equilibria," Chemical Reviews, vol. 1, no. 1, pp. 73-90, 1924.

[78] G. E. Shaw, "Bio-controlled thermostasis involving the sulfur cycle," Climatic Change, vol. 5, no. 3, pp. 297-303, 1983.

[79] J. W. H. Dacey and N. V. Blough, "Hydroxide decomposition of dimethysulfoniopropionate to form dimethylsulfide," Geophysical Research Letters, vol. 14, no. 12, pp. 1246-1249, 1987.

[80] J. W. H. Dacey, G. M. King, and P. S. Lobel, "Herbivory by reef fishes and the production of dimethylsulfide and acrylic acid," Marine Ecology Progress Series, vol. 112, no. 1-2, pp. 6774,1994
[81] P. H. Nienhuis, "Background levels of heavy metals in nine tropical seagrass species in Indonesia," Marine Pollution Bulletin, vol. 17, no. 11, pp. 508-511, 1986.

[82] V. A. Catsiki and P. Panayotidis, "Copper, chromium and nickel in tissues of the Mediterranean seagrasses Posidonia oceanica and Cymodocea nodosa (Potamogetonaceae) from Greek coastal areas," Chemosphere, vol. 26, no. 5, pp. 963978, 1993.

[83] C. Govindasamy, M. Arulpriya, P. Ruban, J. L. Francisca, and A. Ilayaraja, "Concentration of heavy metals in seagrasses tissue of the Palk Strait, Bay of Bengal," Environmental Sciences, vol. 2, no. 1, pp. 145-153, 2011.

[84] C. Lafabrie, C. Pergent-Martini, and G. Pergent, "Metal contamination of Posidonia oceanica meadows along the Corsican coastline (Mediterranean)," Environmental Pollution, vol. 151, no. 1, pp. 262-268, 2008.

[85] L. Marín-Guirao, A. M. Atucha, J. L. Barba, E. M. López, and A. J. García Fernández, "Effects of mining wastes on a seagrass ecosystem: metal accumulation and bioavailability, seagrass dynamics and associated community structure," Marine Environmental Research, vol. 60, no. 3, pp. 317-337, 2005.

[86] L. Li and X. Huang, "Three tropical seagrasses as potential bio-indicators to trace metals in Xincun Bay, Hainan Island, South China," Chinese Journal of Oceanology and Limnology, vol. 30, no. 2, pp. 212-224, 2012.

[87] T. Thangaradjou, S. Raja, P. Subhashini, E. P. Nobi, and E. Dilipan, "Heavy metal enrichment in the seagrasses of Lakshadweep group of islands-a multivariate statistical analysis," Environmental Monitoring and Assessment. In press.

[88] T. Alvarez-Legorreta, D. Mendoza-Cozatl, R. MorenoSanchez, and G. Gold-Bouchot, "Thiol peptides induction in the seagrass Thalassia testudinum (Banks ex König) in response to cadmium exposure," Aquatic Toxicology, vol. 86, no. 1, pp. 12-19, 2008.

[89] A. K. Grennan, "Metallothioneins, a diverse protein family," Plant Physiology, vol. 155, no. 4, pp. 1750-1751, 2011.

[90] C. Cobbett and P. Goldsbrough, "Phytochelatins and metallothioneins: roles in heavy metal detoxification and homeostasis," Annual Review of Plant Biology, vol. 53, pp. 159-182, 2002.

[91] C. A. Blindauer and O. I. Leszczyszyn, "Metallothioneins: unparalleled diversity in structures and functions for metal ion homeostasis and more," Natural Product Reports, vol. 27, no. 5, pp. 720-741, 2010.

[92] T. Giordani, L. Natali, B. E. Maserti, S. Taddei, and A. Cavallini, "Characterization and expression of DNA sequences encoding putative type-II metallothioneins in the seagrass Posidonia oceanica," Plant Physiology, vol. 123, no. 4, pp. 1571-1582, 2000.

[93] R. Cozza, T. Pangaro, P. Maestrini, T. Giordani, L. Natali, and A. Cavallini, "Isolation of putative type 2 metallothionein encoding sequences and spatial expression pattern in the seagrass Posidonia oceanica," Aquatic Botany, vol. 85, no. 4, pp. 317-323, 2006.

[94] S. Wyllie-Echeverria, P. Arzel, and P. A. Cox, "Seagrass conservation: lessons from ethnobotany," Pacific Conservation Biology, vol. 5, no. 4, pp. 333-335, 2000.

[95] P. G. Harrison, "Control of microbial growth and of amphipod grazing by water-soluble compounds from leaves of Zostera marina," Marine Biology, vol. 67, no. 2, pp. 225-230, 1982. 
[96] F. Villa, D. Albanese, B. Giussani, P. S. Stewart, D. Daffonchio, and F. Cappitelli, "Hindering biofilm formation with zosteric acid," Biofouling, vol. 26, no. 6, pp. 739-752, 2010.

[97] C. A. Barrios, Q. Xu, T. Cutright, and B. M. Z. Newby, "Incorporating zosteric acid into silicone coatings to achieve its slow release while reducing fresh water bacterial attachment," Colloids and Surfaces B, vol. 41, no. 2-3, pp. 83-93, 2005.

[98] S. H. Bhosale, V. L. Nagle, and T. G. Jagtap, "Antifouling potential of some marine organisms from India against species of Bacillus and Pseudomonas," Marine Biotechnology, vol. 4, no. 2, pp. 111-118, 2002.

[99] Y. N. Loenko, A. A. Artyukov, E. P. Kozlovskaya, V. A. Miroshnichenko, and G. B. Elyakov, Zosterin, Dal'nauka, Vladivostok, Russia, 1997.

[100] G. Nuissier, F. Diaba, and M. Grignon-Dubois, "Bioactive agents from beach waste: Syringodium flotsam evaluation as a new source of l-chiro-inositol," Innovative Food Science and Emerging Technologies, vol. 9, no. 3, pp. 396-400, 2008.

[101] J. F. Ackerman, "Sexual reproduction of seagrasses: pollination in the marine context," in Seagrass: Biology, Ecology and Conservation, A. W. D. Larkum, R. J. Orth, and C. M. Duarte, Eds., pp. 89-109, Springer, Dordrecht, The Netherlands, 2006.

[102] N. Tanaka, H. Setoguchi, and J. Murata, "Phylogeny of the family hydrocharitaceae inferred from $r b c L$ and matK gene sequence data," Journal of Plant Research, vol. 110, no. 1099, pp. 329-337, 1997.

[103] M. Waycott, D. W. Freshwater, R. A. York, A. Calladine, and W. J. Kenworthy, "Evolutionary trends in the seagrass genus Halophila (Thouars): insights from molecular phylogeny," Bulletin of Marine Science, vol. 71, no. 3, pp. 1299-1308, 2002.

[104] Y. Ito and N. Tanaka, "Hybridisation in a tropical seagrass genus, Halodule (Cymodoceaceae), inferred from plastid and nuclear DNA phylogenies," Telopea, vol. 13, no. 1-2, pp. 219$231,2011$.

[105] Y. Kato, K. Aioi, Y. Omori, N. Takahata, and Y. Satta, "Phylogenetic analyses of Zostera species based on $r b c L$ and matK nucleotide sequences: implications for the origin and diversification of seagrasses in Japanese waters," Genes and Genetic Systems, vol. 78, no. 5, pp. 329-342, 2003.

[106] D. H. Les, M. L. Moody, S. W. L. Jacobs, and R. J. Bayer, "Systematics of Seagrasses (Zosteraceae) in Australia and New Zealand," Systematic Botany, vol. 27, no. 3, pp. 468-484, 2002.

[107] G. Procaccini, L. Mazzella, R. S. Alberte, and D. H. Les, "Chloroplast tRNA(Leu) (UAA) intron sequences provide phylogenetic resolution of seagrass relationships," Aquatic Botany, vol. 62, no. 4, pp. 269-283, 1999. 

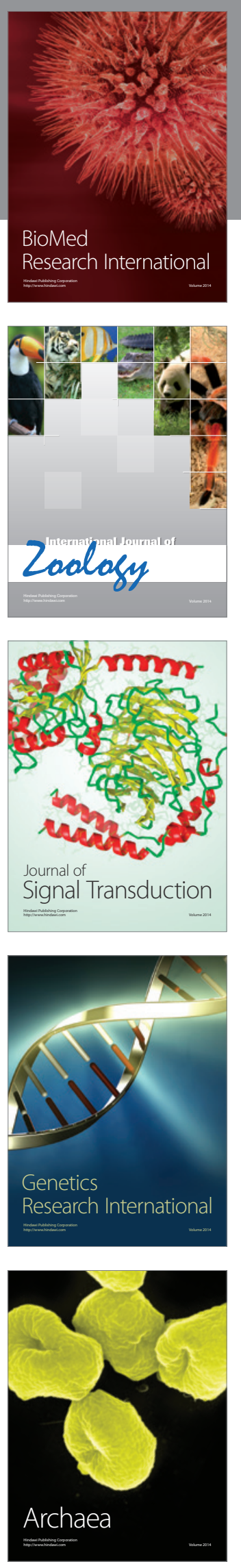
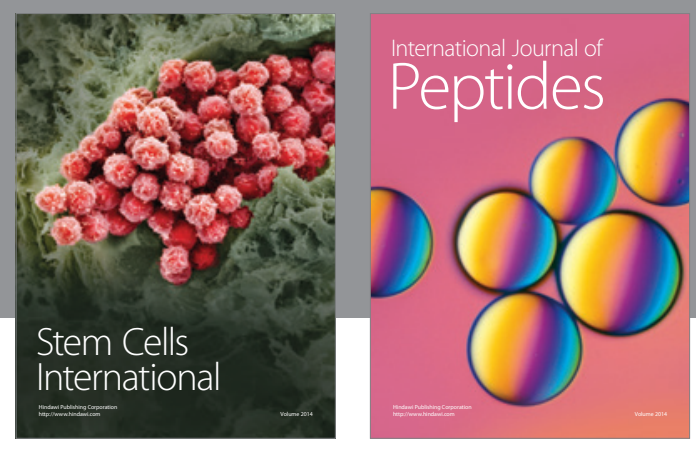

Submit your manuscripts at

http://www.hindawi.com
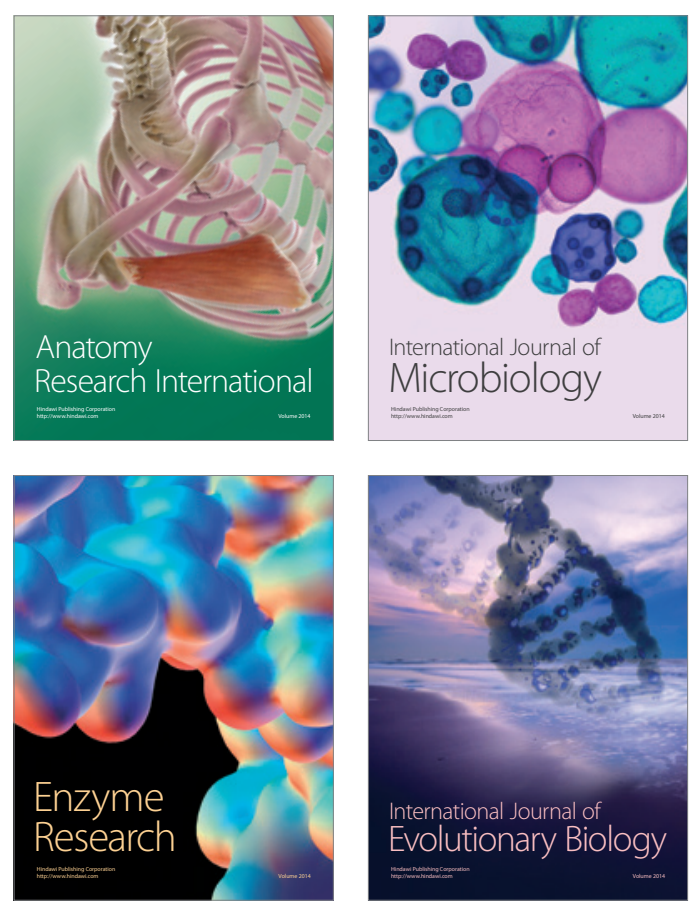
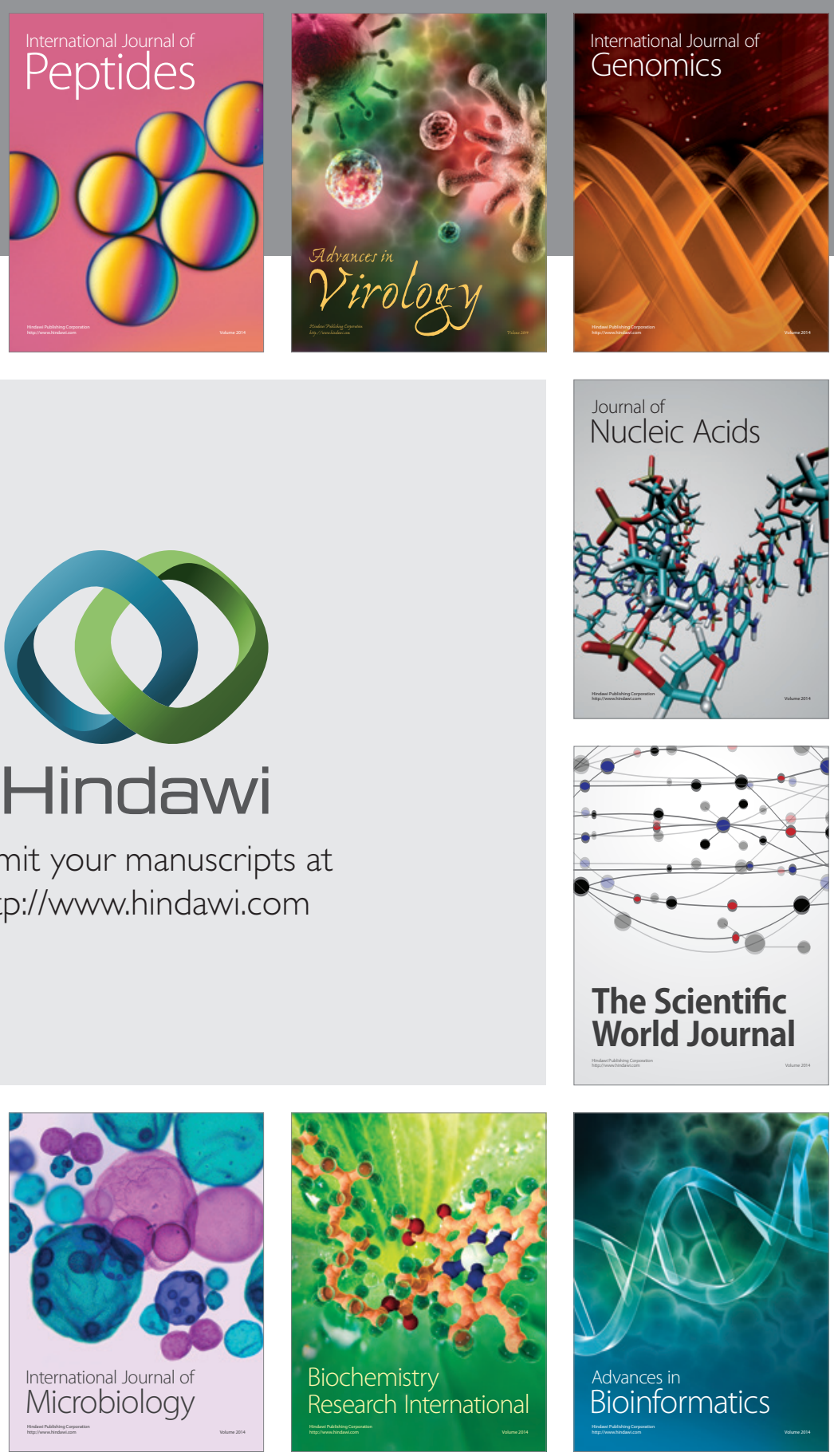

The Scientific World Journal
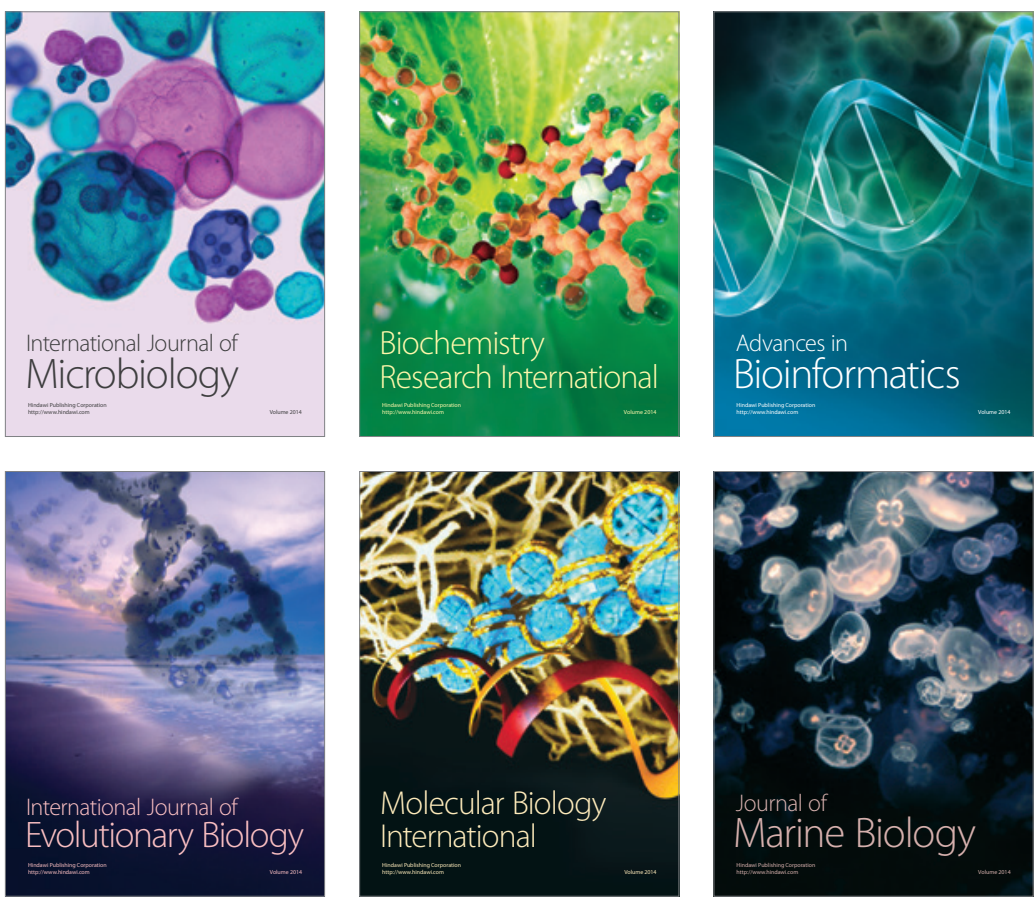